\title{
Public Policy in Support Of SMALl BUSINESS: THE AMERICAN EXPERIENCE
}

\author{
BY: BEN R. CRAIG, WILLIAM E. JACKSON III AND \\ JAMES B. THOMSON ${ }^{*}$
}

\begin{abstract}
Information problems in small enterprise credit markets can result in a market equilibrium characterized by credit rationing. These information problems are potentially more severe during sharp economic downturns such as the recent Great Recession. Government interventions to alleviate credit constraints on small firms need to be designed to correct the specific market failure resulting in socially suboptimal credit flows. We argue that Small Business Administration loan guarantees are a potentially appropriate intervention and provide a review of empirical research that supports our contention.
\end{abstract}

\section{THE AMERICAN EXPERIENCE}

Propagated largely by a boom and bust cycle in the residential real estate market, the financial crisis of 2007-2009 spilled over into the real economy producing the longest business cycle downturn of the post war era. ${ }^{1}$ The Great Recession, as it became to be known, sparked a political response that included the appropriation of $\$ 700$ billion for the Troubled Asset Relief Program (TARP) in the Fall of 2008 to rehabilitate the financial system by shoring up the balance sheets of major financial firms. ${ }^{2}$ This was followed by The American Recovery and Reinvestment Act of 2009 , commonly referred to as the stimulus package, which provided for

\footnotetext{
*Ben Craig and James Thomson are economists in the research department at the Federal Reserve Bank of Cleveland. William E. Jackson III is the Smith Foundation Chair of Business Ethics and Integrity at the University of Alabama. The views expressed herein are those of the authors and not those of the Federal Reserve Bank of Cleveland, or the Board of Governors of the Federal Reserve System.

${ }_{1}$ According to the National Bureau of Economic Research (NBER) the Great Recession started in December of 2007 and ended in June of 2009. See Business Cycle Dating Committee, NAT'L BuREau OF ECON. RESEARCH (Sept. 20, 2010), http://www.nber.org/cycles/sept2010.html.

${ }^{2}$ For a description of TARP, see Troubled Asset Relief Program (TARP) Information, BD. GOVERNORS FED. RES. SYS. (Apr. 21, 2010), http://www.federalreserve.gov/bankinforeg/tarpinfo.htm.
} 
$\$ 862$ billion in new federal expenditures to combat the continued slowdown in economic activity. ${ }^{3}$ In both cases, opening up the public purse was seen as an antidote to the collapse in economic activity.

TARP was part of efforts to restore credit flows, particularly bank lending, in an effort to kick-start economic growth. Of particular concern would be access to credit by small businesses who would be most affected by a retrenchment of bank lending. After all, unlike large firms, small businesses cannot directly access capital markets. Hence, the continued decline in bank credit facilities and especially bank commercial credit facilities from the onset of the crisis through the end of 2010 is likely to have a disproportionate impact on growth in the small business sector. ${ }^{4}$ This in turn could affect the strength and sustainability of the economic recovery.

Concerns about access to credit for small business, particularly when there is a retrenchment in the growth of bank supplied credit, are grounded in economic theory-information problems in credit markets can lead to credit rationing. Greater uncertainty during business cycle downturns has the potential to exacerbate credit rationing. So it is not surprising that calls for government intervention into small enterprise credit markets reach a crescendo during the trough of the credit cycle.

Even in the best of times small businesses have enjoyed wide political support as evidenced by the large number and variety of subsidies, direct and indirect, which have been directed to the small business sector. ${ }^{5}$ Whether government intervention in small enterprise credit markets is warranted is not the central issue here. Rather, it is whether the net social

\footnotetext{
${ }^{3}$ John F. Cogan \& John B. Taylor, What the Government Purchases Multiplier Actually Multiplied in the 2009 Stimulus Package (Nat'l Bureau of Econ. Res., Working Paper No. 16505, 2010), available at http://www.federalreserve.gov/ bankinforeg/tarpinfo.htm.

${ }^{4}$ See Matthew Koepke \& James B. Thomson, Economic Trends: Bank Lending, FED. RESERVE BANK OF CLEVELAND (Mar. 23, 2011), $\mathrm{http} / / / \mathrm{www} . c l e v e l a n d f e d . o r g /$ research/trends/201 1/0411/0lbanfin.cfm?WT.oss=Ec onomic Trends: Bank Lending\&WT.oss $r=2190$.

${ }^{5}$ Direct subsidies to small businesses include tax breaks (subchapter $\mathrm{S}$ organizational form), direct loans and loan guarantees. Indirect subsidies to this sector of the economy include funding-related subsidies available to lenders such as the ability for community financial institutions to pledge small business and small farm loans as collateral for advances from the Federal Home Loan Banks and a lower capital charge for bank small business loan portfolios in the Basel II international capital accords. For a discussion of the use of small business loans as collateral for Federal Home Loan Bank Advances, see Ben R. Craig \& James B. Thomson, Federal Home Loan Bank Lending to Community Banks: Are Targeted Subsidies Desirable?, 23 J. FIN. SERVICE RES. 5, 6 (2003). A discussion of the firm size adjustment for bank capital in Basel II can be found in International Convergence of Capital Measurement and Capital Standards: A Revised Framework, THE BASEL COMM. ON BANKING SUPERVISION 78 (2006), available at http://www.gpoaccess.gov/fcic/fcic.pdf.
} 
benefit of a particular intervention is positive - weighing in the direct cost of the intervention and the costs associated with the unintended impact of government interventions on private incentives. For this to be the case, the intervention should be designed to correct the market failure. Small Business Administration (SBA) loan guarantees are arguably such an intervention.

In what follows we present evidence that bank lending and in particular small business lending has declined over the recent economic downturn. We then describe the economics of small enterprise credit markets. Next, we outline how in theory SBA loan guarantees can help complete the market. We then provide an overview of some of our empirical work on SBA loan guarantees that supports our contention that SBA loan guarantees are one of the few government interventions in small enterprise credit markets that may produce positive net social benefits.

\section{A. Bank Lending Over the Recent Economic Cycle}

The onset of the financial crisis in 2007 and the sharp business cycle downturn that followed produced a sharp retrenchment in credit markets. Of greatest concern for the small business sector was the contraction of bank lending. Figure 1 shows that business loans on the balance sheets of Federal Deposit Insurance Corporation (FDIC) insured banks and thrifts grew throughout most of the past decade, while business loan balances and small business loan balances contracted sharply in mid-2009. Small business loan balances held by FDIC-insured institutions have continued to decline through the first quarter of 2011.

\section{Figure 1: Small Business Loan Balances}

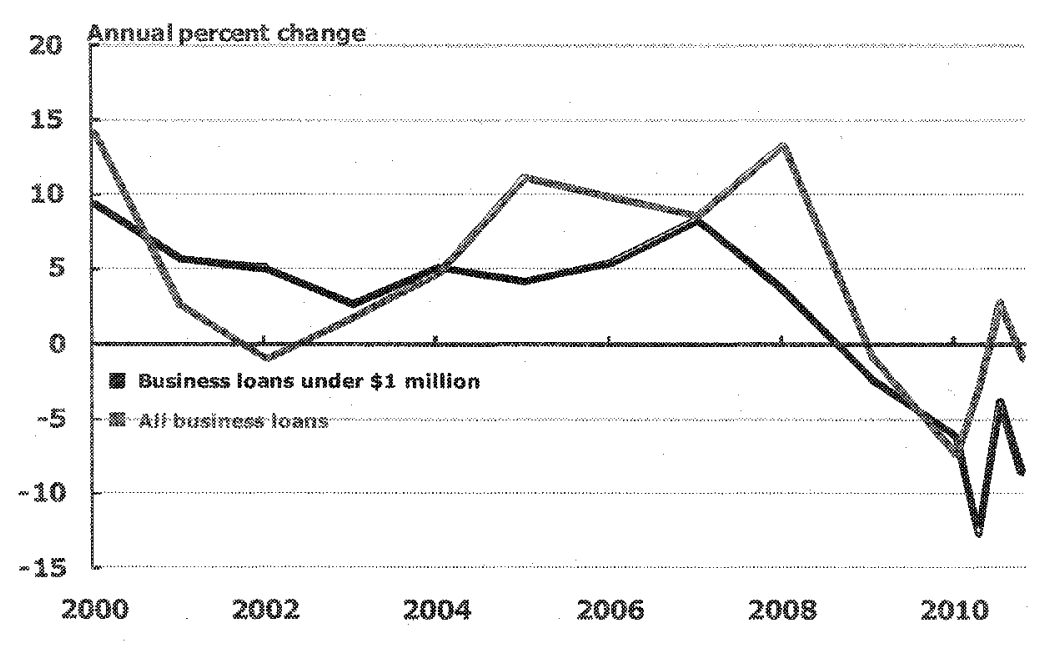

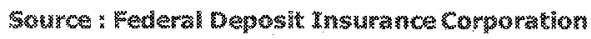


This decline in small business loan balances appears to be driven by both a contraction in loan supply and a retrenchment in loan demand. As seen in Figure 2, the Federal Reserve's Senior Loan Officer Opinion survey shows a ratcheting up of underwriting standards starting in the Fourth Quarter of 2007 and a decline in small business loan demand starting in Fourth Quarter of 2006. While there seems to be some reversal in these trends since the middle of 2010 , small business loan balances at FDICinsured institutions showed few signs of rebounding in early 2011.

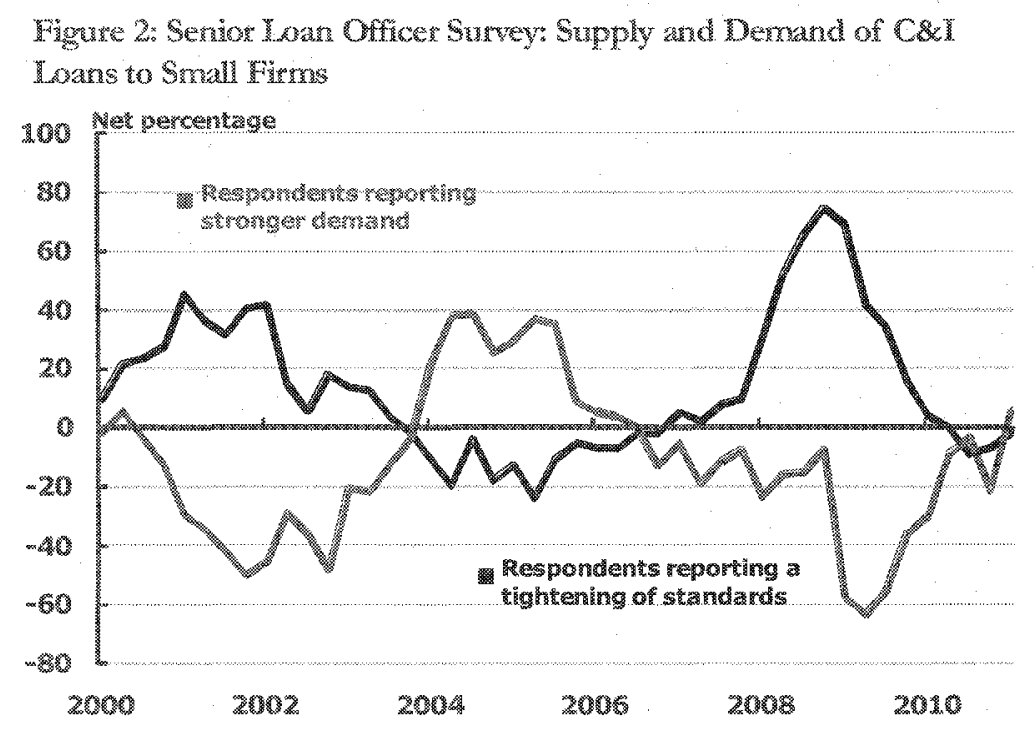

worrece:

The decline in small business loan balances at FDIC-insured banks and thrifts is of concern because, for reasons outlined in the next section, the small business sector is particularly dependent on banks and thrifts for credit. According to the Federal Reserve's 2003 Survey of Small Business Finances, $96 \%$ of small businesses surveyed relied on depository institutions for at least one financial service. ${ }^{6}$ Commercial banks were listed as the most common source of business credit (lines of credit, loans and capital leases) with $41 \%$ of small businesses surveyed relying on banks for one or more of these credit products.

Concerns about the decline in credit access by small firms are only heightened when one considers recent evidence on indirect bank credit. That is, credit used by entrepreneurs to fund their businesses that does not

\footnotetext{
${ }^{6}$ Traci L. Mach \& John D. Wolken, Financial Services Used by Small Businesses: Evidence from the 2003 Survey of Small Business Finances, 92 FED. RES. BULL. A167, A184 (Oct. 2006), available at http://www.federalreserve.gov/pubs/bulletin/ 2006/smallbusiness/smallbusiness.pdf.

${ }^{7}$ Id. at $\mathrm{A} 186$.
} 
show up on a bank's books as a business loan, such as credit cards and home equity lines of credit. A recent article details the impact of the disruption of the securitization market on small business access to credit. ${ }^{8}$ Specifically, it shows that just prior to the financial crisis, the broad credit markets provided nearly $23 \%$ of small business credit-much of this in the form of securitized bank lending. ${ }^{9}$ The sharp contraction at the onset of the financial crisis in the issuance of asset-backed securities and collateralized mortgage obligations, two sources of off-balance sheet financing of small firm credit, further reduced credit sources for small business. ${ }^{10}$

Small business finances have been further constrained by the 2006 downturn in housing prices. After all, an important source of credit for small business owners is the equity in their homes. ${ }^{11}$ While the importance of home equity lines of credit as a source of small business financing is difficult to document precisely, the available evidence shows that in 2007 the median balance on a home equity line of credit for self-employed households was more than double that of households that were not small business owners. ${ }^{12}$ Moreover, it is estimated that the housing market collapse starting in 2006 has been accompanied by a $\$ 31.5$ billion reduction in home equity lines of credit, with the largest declines in these lines in states with the biggest home price correction. ${ }^{13}$

\section{B. The Economics of Small Enterprise Credit Markets}

Fundamental information problems in small enterprise credit markets can produce a market equilibrium that is inefficient as lenders undersupply loans. While deviations from market efficiency may be slight, and hence, do not merit corrective public intervention, there are cases where information problems are severe enough that they lead to credit rationing and constitute the failure of the credit market. In their seminal work on information problems in credit markets, Joseph Stiglitz and Andrew Weiss demonstrate that price alone may not equilibrate demand and supply in credit markets. ${ }^{14}$ They also show that the corresponding disequilibrium would unlikely be just a temporary phenomenon.

\footnotetext{
${ }^{8}$ James A. Wilcox, Securitization and Small Business, 22 FED. RES. BANK OF S.F. ECON. LETTER, 1 (July 18, 2011), available at http://www.frbsf.org/publications/ economics/letter/2011/el2011-22.pdf.

9 Id. at 3, Figure 1.

${ }^{10}$ Id. at 4, Figure 2 .

${ }^{11}$ See Mark E. Schweitzer and Scott A. Shane, The Effect of Falling Home Prices on Small Business Borrowing, 18 FED. RES. BANK OF CLEVELAND ECON. COMMENT. (Dec. 20, 2010), available at http://www.clevelandfed.org/research/ commentary/2010/2010-18.pdf.

${ }_{12}^{12}$ Id. at 3 , Figure 2.

13 Id. at 4, Figure 3.

14 Jospeh E. Stiglitz \& Andrew Weiss, Credit Rationing in Markets with Imperfect Information, 71 AM. ECON. REV 393 (1981).
} 
Importantly, Stiglitz and Weiss show that in equilibrium a loan market may be characterized by credit rationing. They reason that banks making loans are concerned about the interest rate they receive on the loan and the risk of the loan. However, the interest rate may itself affect the risk of the pool of bank loans by either sorting potential borrowers (the adverse selection effect) or influencing the actions of borrowers (the moral hazard effect). Both effects derive directly from the imperfect information that is present in loan markets after banks have evaluated loan applications. When the price (interest rate) affects the nature of the transaction, it is unlikely that price will also clear the market. ${ }^{15}$

The adverse selection effect is a consequence of different borrowers having different likelihoods of repaying their loans, a probability known to the borrowers but not the lenders. The expected return to the bank on a loan obviously depends on the probability of repayment, so the bank would like to be able to identify borrowers who are more likely to repay. It is difficult to identify such borrowers, partially because the borrowers have more information than the lender. ${ }^{16}$ Typically, the bank will use a variety of screening devices to do so. The interest rate that a borrower is willing to pay may act as one such screening device. For example, those who are willing to pay a higher interest rate are likely to be, on average, worse risks if borrowers are willing to borrow at a higher interest rate because they perceive their probability of repaying the loan to be lower. So, as the interest rate rises, the average "riskiness" of those who are willing to borrow increases, and this may actually result in lowering the bank's expected profits from lending.

Similarly, as the interest rate and other terms of the contract change, the behavior of the borrower is also likely to change. For instance, raising the interest rate decreases the payoffs of successful projects. Higher interest rates may thus induce firms to undertake riskier projects-projects with lower probabilities of success but higher payoffs when successful. In other words, the price a firm pays for credit may affect the riskiness of its investment decisions, which is the moral hazard problem.

As a result of these two effects, a bank's expected return may increase less for an additional increase in the interest rate; and, beyond a certain point, may actually decrease as the interest rate is increased. Clearly, under these conditions, it is conceivable that the demand for credit may exceed

${ }^{15}$ In the absence of adverse selection, lenders could simply offer loan rates to borrowers that reflected the average risk of the pool of borrowers. This is because each loan made would reflect a random draw from the pool of borrowers. If the bank made a large number of small loans to borrowers in the pool then the bank's loan portfolio would have the same risk and return characteristics of the pool of borrowers.

${ }^{16}$ See Stewart C. Myers \& Nicholas S. Majluf, Corporate Financing and

Investment Decision When Firms Have Information That Investors Do Not Have,

13 J. OF FIN. ECON.187, 195-96 (1984). 
the supply of credit in equilibrium. ${ }^{17}$ Although traditional analysis would argue that in the presence of an excess demand for credit, unsatisfied borrowers would offer to pay a higher interest rate to the bank, bidding up the interest rate until demand equals supply, it does not occur in this case. This is because the bank will not lend to someone who offers to pay the higher interest rate, as such a borrower is likely to be a worse risk than the average current borrower. The expected return on a loan to this borrower at the higher interest rate may actually be lower than the expected return on the loans the bank is currently making. Hence, there are no competitive forces leading supply to equal demand, and credit is rationed.

As a single price cannot clear the lending market, a "second price" or screening mechanism may be required. Examples of second prices in lending markets include: the use of credit scores, collateral, loan commitments (which involve two-part pricing, a fixed fee for the line of credit and lending rate attached to the loan) and relationships. Relationships are a form of informal loan commitment and have been recognized by economists as an important market mechanism for reducing credit rationing. ${ }^{18}$ Lending is based on limited information on the quality of borrowers in the market, but a close and continued interaction between a firm and a bank may provide a lender with sufficient information about, and a voice in, the firm's affairs so as to lower the cost and increase the availability of credit. Conditional on its positive past experience with the borrower, the bank may expect future loans to be less risky, which should reduce its average cost of lending and increase its willingness to provide funds.

The relationship-lending literature suggests that in addition to being formed over time, relationships can be built through interaction over multiple products. That is, borrowers may obtain more than just loans from a bank. Borrowers may purchase a variety of financial services such as checking and savings accounts. These added dimensions of a relationship can affect the firm's borrowing cost in two ways. First, they increase the precision of the lender's information about the borrower. For example, the

\footnotetext{
${ }^{17}$ See Allen N. Berger \& Gregory F. Udell, The Economics of Small Business Finance: The Roles of Private Equity and Debt Markets in the Financial Growth Cycle 22(8) J. BANKING \& FIN. 613 (1998); Ari Hyytinen \& Lotta Väänänen, Where Do Financial Constraints Originate From: An Empirical Analysis of Adverse Selection and Moral Hazard in Capital Markets, 27 SMALL Bus. ECON. 323 (2006).

${ }^{18}$ See Allen N. Berger \& Gregory F. Udell, Relationship Lending and Lines of Credit in Small Firm Finance, 68(3) J. Bus. 351 (1995); Edward J. Kane \& Burton G. Malkiel, Bank Portfolio Allocation, Deposit Variability, and the Availability Doctrine, 79(1) Q. J. ECON. 113 (1965); Mitchell A. Peterson \& Raghuram G. Rajan, The Benefits of Lending Relationships: Evidence From Small Business Data, 49(1) J. FIN. 3 (1994).
} 
lender can learn about the firm's sales by monitoring the cash flowing through its checking account or by factoring the firm's accounts receivables. Second, the lender can spread any fixed costs of monitoring the firm over multiple products.

Overall, the available evidence points to a significantly positive relationship between factors related to the strength and duration of the lending relationships among banks and small business customers and both the terms (lower loan rates and fewer loan covenants) and availability of credit. From the perspective of the banks, the stronger the relationship, the more likely the borrower is to select the bank for future credit needs and other banking services. However, because relationships may be more costly for small businesses to establish relative to large businesses, and because lack of relationships may lead to severe credit rationing in the small business credit market, some form of government intervention to assist small businesses in establishing relationships with lenders may be appropriate.

\section{SBA LOAN GUARANTEES}

SBA loan guarantees may improve credit allocation by providing a mechanism for pricing loans that is independent of borrower behavior. In other words, loan guarantees are another way of mitigating credit rationing in small enterprise loan markets. They serve as a substitute for collateral and/or relationships in the loan decision process and in theory should result in an increase in credit extended to small businesses. By reducing the downside losses associated with loan defaults, the guarantee allows the lender to charge a lower interest rate on the loan, which reduces both the adverse selection and moral hazard problems. In addition, SBA loan guarantee programs may improve the intermediation process by lowering the risk to the lender of extending longer-term loans, ones that more closely meet the needs of small businesses for capital investment. As such, SBA loan guarantee programs potentially improve credit allocation in small enterprise loan markets by providing a better set of market completion services than private remedies alone. Of course, as any government intervention into markets, SBA loan guarantees likely distort credit markets in unintended ways-possibly resulting in an oversupply of loans to small enterprises and reducing economic efficiency. Ultimately, the net effect of SBA loan guarantees is an empirical question that we have looked at in a number of earlier papers. ${ }^{19}$

\footnotetext{
${ }^{19}$ See Ben R. Craig, William E. Jackson III \& James B. Thomson, Credit Market Failure Intervention: Do Government Sponsored Small Business Credit Programs Enrich Poorer Areas? 30(4) SMALL BUS. ECON. 345 (2008); Ben R. Craig, William E. Jackson III \& James B. Thomson, SBA-Loan Guarantees and Local Economic Growth, 45 J. SMALL BUS. MGM'T. 116 (2007).
} 
The empirical question of interest to us was whether SBA loan guarantees improve the functioning of small business credit markets-a necessary condition for them having net social benefits. Unfortunately, data limitations precluded us from directly testing this hypothesis. Consequently, we turned to an indirect approach. A necessary condition for SBA loan guarantees to have net positive social benefits is that they have a positive impact on economic outcomes. As the effect of these programs would be the greatest at the local level, we focused our analysis there. What we did in our papers is test whether a measure of SBA loan guarantees, scaled to a market, impact measures of local economic performance-using Metropolitan Statistical Areas (MSAs) and rural (non-MSA) counties as our definition of the local market. Our sample period ran from 1991 through 2001. Depending on the nature of the question asked we used either per capita personal income or employment as the measure of economic performance. $^{20}$

Overall, our work found evidence consistent with SBA loan guarantees improving the allocation of credit in small business loan markets. In Craig, Jackson, and Thomson (2008), we found a positive and significant correlation between the average annual level of employment in a local market and the level of SBA guaranteed lending in that local market. ${ }^{21}$ The intensity of this correlation is relatively larger in low-income markets. ${ }^{22}$ Indeed, one interpretation of our results is that this correlation is positive and significant only in low-income markets. ${ }^{23}$ In Craig, Jackson, and Thomson (2007) we found that the level of SBA-guaranteed lending activity (per $\$ 1000$ of deposits) is positively related to the growth of per capita income at the local market level—-for both urban and rural markets. ${ }^{24}$ The impact of SBA-guaranteed lending on growth appears to be small. ${ }^{25}$ However, this small measurable economic impact of SBA loan guarantees on local economic growth is expected given the limited role they play in the overall (small and large firm) credit intermediation process. We have extended these basic results in a number of ways to get a better idea of what is driving the positive relationship between measures of SBA loan guarantees and local economic performance. ${ }^{26}$ In those papers we also find

\footnotetext{
${ }^{20}$ For a more detailed description of the empirical experiment, data and sample period see Craig, Jackson \& Thomson (2007), supra note 19, at 122-24; Craig, Jackson \& Thomson (2008), supra note 19, at 351-53.

${ }_{22}^{21}$ Craig, Jackson \& Thomson (2008), supra note 19, at 345.

${ }^{22} \mathrm{Id}$.

${ }^{23}$ Craig, Jackson \& Thomson (2008), supra note 19, at 351-53.

${ }_{24}^{24}$ Craig, Jackson \& Thomson (2007), supra note 19, at 122-24

25 Id. at 116.

${ }^{26}$ Ben R. Craig, William E. Jackson III \& James B. Thomson, On Government Intervention in the Small Firm Credit Market and Economic Performance, ENTREPRENEURSHIP IN EMERGING DOMESTIC MARKETS: BARRIERS AND INNOVATION 47 (2007). Extensions of our work can be found in Ben R. Craig, William E. Jackson III and James B. Thomson, Does Small Business Administration Guaranteed Lending Improve Economic Performance in Low-
} 
that the relationship between SBA loan guarantees and local economic performance is stronger in markets with high shares of minority populations and in less-financially developed areas. ${ }^{27}$

The results from our studies need to be interpreted with caution. For one, data limitation does not allow us to control for small-business lending at the local market level, so we do not know whether SBA loan guarantee programs are contributing to economic performance by helping to complete the market for small firm credit or whether they are simply proxying for small business lending in the market. This might be the case if there is a positive correlation between the level of SBA loan guarantees and small business lending in a market. Second, we are not able to test whether SBA loan guarantees materially increase the volume of small business lending in a market-are SBA guaranteed credits simply being substituted for nonguaranteed small business loans? This question gets to the heart of whether SBA programs improve social welfare because it is related to who captures the subsidy associated with SBA loan guarantees. In other words, finding a positive correlation between measures of SBA guarantees and local economic performance is only the first step towards establishing the desirability of these programs. More evidence is needed to establish that SBA guaranteed lending programs are welfare enhancing.

\section{CONCLUSIONS}

Small businesses are likely to remain a sacred cow of public policy. The popular view, founded or unfounded, that small businesses are the engine of economic growth and development means they are likely to enjoy continued government support-consternation by policymakers over the terms and access to credit by small business in the most recent economic cycle is consistent with this view. However, government interventions into small enterprise credit markets are likely to produce net social benefits only

Income Areas? Entrepreneurship in Low- and Moderate- Income CommunitiesI, 2010(18) Economic Commentary 55, available at http://www.kansascityfed.org/ publicat/commaffrs/08\%20Jackson.pdf; Ben R. Craig, William E. Jackson III and James B. Thomson, 2006, On SBA Guaranteed Lending and Economic Growth (Fed. Res. Bank of Cleveland Working Paper 04-03, 2004); Ben R. Craig, William E. Jackson III \& James B. Thomson, Small Firm Credit Market Discrimination, Small Business Administration Guaranteed Lending, and Local Market Economic Performance, 613 (1) ANNALS AM. ACAD. OF POL. SOC. SCI. 73 (2007); Craig Armstrong, Ben R. Craig, William E. Jackson III \& James B. Thomson, The Importance of Financial Market Development on the Relationship Between Loan Guarantees for SMEs and Local Market Employment Rates (Federal Reserve Bank of Cleveland, Working Paper 10-20, 2010); Ben R. Craig, William E. Jackson III \& James B. Thomson, 2006, Does Small Business Administration Guaranteed Lending Improve Economic Performance in Low-Income Areas?, 55-85; Conference, Entrepreneurship in Low- and Moderate- Income Communities (2006).

${ }_{27}$ Craig, Jackson \& Thomson (2007), supra note 26, at 90-91. 
in those cases where the intervention is motivated by and designed to correct a market failure. Loan guarantee programs such as those offered by the Small Business Administration may be one such intervention. Moreover, in our previous work on SBA loan guarantees we find evidence that is consistent with SBA loan guarantees producing positive net social benefits. Considerably more work, however, needs to be done before the desirability of this government intervention can be established. 
